\title{
Effect of Trade Liberalization on Low-Carbon Energy Technology Dissemination in Asia*
}

\author{
Venkatachalam Anbumozhi \\ Economic Research Institute for South East Asia \\ Sentral Senayan II \\ 6th floor Jalan Asia Afrika No. 8 \\ Gelora Bung Karno, Senayan \\ Jakarta Pusat 10270, Indonesia
}

\section{Kaliappa Kalirajan}

Crawford School of Public Policy

Australian National University

Canberra, ACT 260I, Australia

kaliappa.kalirajan@anu.edu.au

\begin{abstract}
The production and use of low-carbon energy technology and services, such as renewable energy, are imperative for Asia's emerging economies (which are heavily dependent on imported energy and resources) to tackle global environmental issues like climate change. Acknowledging this fact, recently, governments in the Asian region individually have been taking effective actions in the form of voluntary targets and policy commitments to improve the production and use of low-carbon technology, such as solar, wind, geo-thermal, and so forth. Nevertheless, the diffusion of these technologies has been through liberalized trade, which has been low compared with trade and investment in other energy intensive sectors. Though effective tariffs are low, non-tariff barriers or behind-the-border constraints are very high. In this exploratory study, the potential for increased exports in low-carbon technology and services under a grand regional coalition, partial regional coalition, and stand alone scenarios is studied. We find that production, trade, and investment in renewable energy technologies are very low regionally. There is a large gap between the demand for and the supply of low-carbon energy technology and associated pollution abatement services. Behind-the-border constraints that exist within the exporting country, such as poor infrastructure and inefficient institutions, create this gap between actually realized and potentially possible exports. This supply gap provides an opportunity for those emerging Asian economies, which have the potential to contribute to the manufacturing of such technologies individually and collectively pooling their physical and human capital.
\end{abstract}

\section{Introduction}

The production and use of low-carbon energy technology, such as solar, wind, energy efficiency equipment, and other related services, are imperative for Asia's emerging

* We are grateful to Zhao Zen, Iris Claus and participants in the conferences and seminars for useful comments and helpful discussion. 
economies, which are heavily dependent on imported energy and resources. In the last decade, low-carbon technology is also receiving increasing attention worldwide as a way to overcome global warming and achieve commitment to implement intended nationally determined contributions. Acknowledging this fact, recently, governments in the Asian region individually have been taking effective actions in the form of voluntary targets and policy commitments to improve the production and use of low-carbon technology (Kawai and Wignaraja 2008). The observed effects of these commitments, however, are often challenged by many constraints such as technological barriers, financial deficiencies, and lack of human capital, some of which are very specific to developing Asia (NDRC 2009; Mikic 2010). Although different sectoral policies, such as trade, environment, and investment policies that aim to facilitate private enterprises, households, and government agencies to contribute to sustainable development through the use of renewable energy technologies, are being implemented at the national level, fears of competitive disadvantage mean that policies need to be driven by global and regional frameworks that encompass all countries and sectors.

Trade can easily be identified as East Asia's and Southeast Asia's growth engine contributing to increased energy demand (Lackner 2005; Sjöholm and Kundin 2010). It is interesting to note from the literature that production networks have more extensively spread in East Asia than other countries (Ando and Kimura 2003; Kimura and Ando 2005; Gill and Karas 2007), dominated by vertical intra-industry trade, which several countries participate in at various stages of the production chain (Wakasugi 2007). It should also be noted that as regional income increases, the demand for energy and environmental goods and services is expected to rise. In this context, the interesting question is whether developing Asian countries can significantly contribute to closing the gap between the demand for and supply of low-carbon energy sources and allied services in the region. As some of the low-carbon goods and services, such as biomass boilers, solar panels, and wind turbines, are labor intensive, drawing on the Heckscher-Ohlin theory, it is customary to argue that developing countries with a relative abundant supply of low-skilled labor should concentrate on labor-intensive goods production and exports. Empirical studies (Choi 2001; Sung 2012; Kodama and Inui 2015; Chia 2015), however, have asserted that mere relative abundance in low-skilled labor does not guarantee sustained growth of labor-intensive exports, if countries do not have good logistics including transportation and telecommunication infrastructure. Thus, labor availability should be complemented with improved physical and institutional infrastructure (Song 2015; Wignarja et al. 2015). Nevertheless, trade and investment in low-carbon energy technology and environmental services are low compared to trade and investment in other energy intensive sectors (Mikic 2010). Though effective tariffs are low, non-tariff barriers or behind-the-border constraints are high (Mikic 2010). In this context, the need for regional cooperation toward building and sustaining physical and institutional infrastructure assumes added importance (Streets 2005). An exploratory study in this area of how intra-regional cooperation 
can be achieved in trade and investment in low-carbon energy systems and associated environmental services will be useful for policymakers.

In this context, the objectives of this research are (i) to measure the potential for major developing economies to increase exports in low-carbon technology and services under a grand regional coalition, partial regional coalition, and stand alone scenarios; and (ii) to measure the impact of existing behind-the-border constraints on potential exports in emerging Asian economies.

\section{Methodology}

The current patterns of trade and investment in low-carbon goods and services in large economies of Asia, which are identified based on their energy consumption and carbon emissions, are examined. Eight countries (China, India, Indonesia, Malaysia, the Philippines, Singapore, Thailand, and Vietnam) are selected for the study. Export flows (EX) in low-carbon energy technology and allied services between two countries ( $i$ and $j$ ) are determined by the following factors, and illustrated in Figure 1.

First, the energy demand for and supply of goods, which are usually proxied by gross domestic product (GDP), and population (POP) of the exporting and importing countries, and the geographical distance (D) between countries, are expected to influence exports. These factors may be named "natural determinants" of export flows between countries. Second, relative prices of the imported goods, which are mainly influenced by the tariff $(\mathrm{T})$ structure of the importing country, would also influence export flows and may be named changes in "explicit beyond-the-border determinants." Third, different kinds of institutional and infrastructural rigidities that exist in the exporting country may influence exports negatively and these factors may be referred to as "behind-the-border determinants" in the home country, which are under the control of the exporting country. Fourth, different kinds of institutional and infrastructural rigidities that exist in the importing country could also influence export flows negatively, and these factors may be called "implicit beyond-the-border determinants," which are beyond the control of the exporting country. Fifthly, bilateral and multilateral trade negotiations in the form of improvement in trade promotion and facilitation policies of both home and partner countries are expected to influence export flows positively. A dummy variable $\left(D_{1}\right)$ can be used to represent whether there are such trade agreements between countries and influence of these factors on exports may be called "mutually induced determinants."

Another variable (FDI) is the ratio of foreign direct investment from Asia to FDI in the home country lagged one period, which is used as a proxy for regional integration. Here, it becomes necessary to elaborate briefly on the type of FDI used in this study. "The limited understanding of the role of FDI in promoting low-carbon energy system objectives 


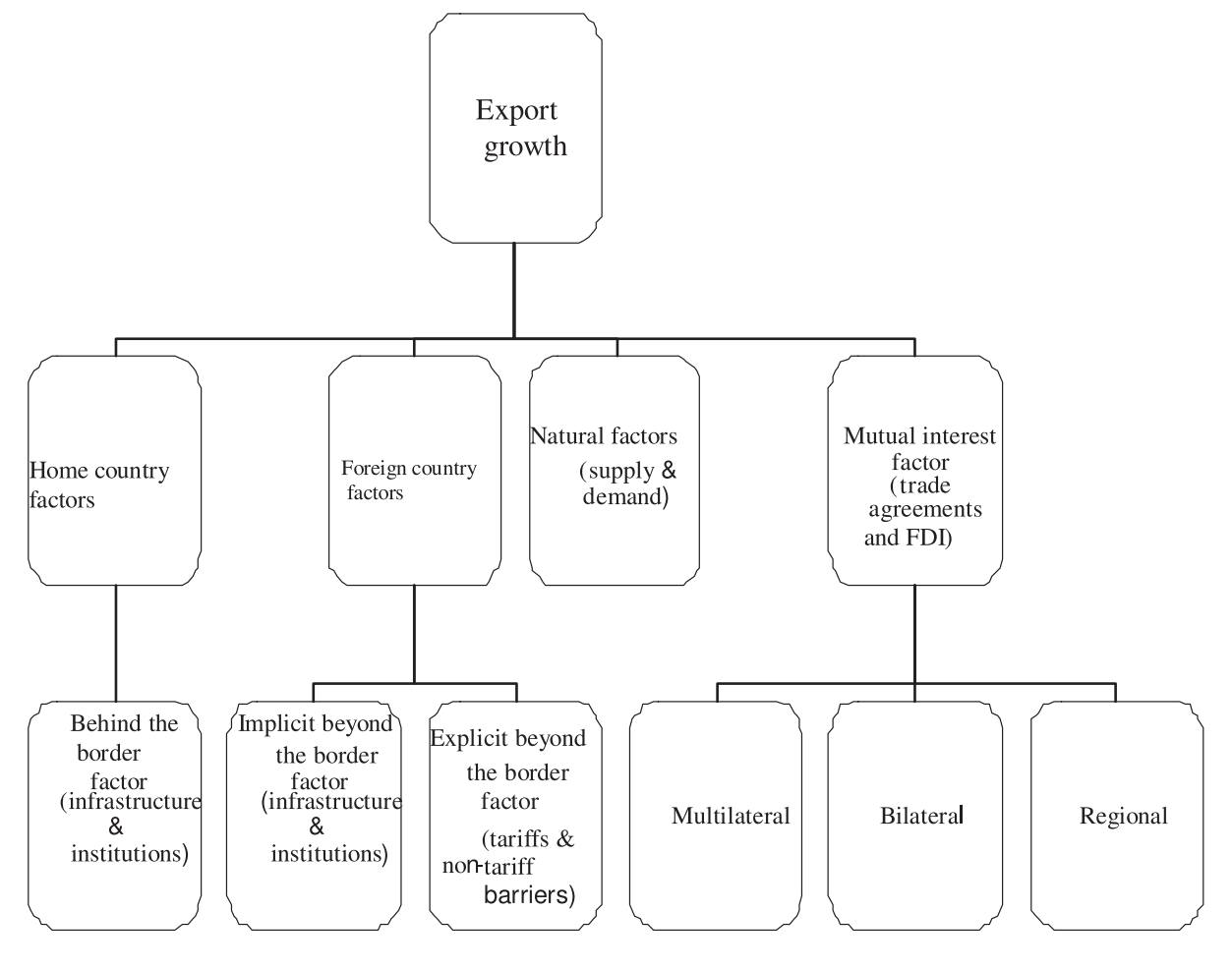

is largely due to the lack of an internationally agreed definition of and relevant data on green FDI" (Golub, Kaufmann, and Yeres 2011, 7). Further, there is no uniform data available on FDI in the WTO 153 list of low-carbon energy systems and other related services, for the selected emerging economies in Asia over the period of analysis.

Most importantly, particularly for FDI, low-carbon activity is often not associated so much with a particular good or service, but rather multiple range of technology, which is very difficult to apprehend statistically. There is an important role for FDI in manufacturing sectors and industries that are high energy intensive by nature but where the potential for energy efficiency improvement and pollution abatement is important. The latter dimension would not be captured if the definition was limited to investment in environmental goods (EGS). (Golub, Kaufmann, and Yeres 2011, 16)

Therefore, total FDI is used in the following model to explain the export flows of lowcarbon energy technology and associated services. 
The impact of the "grand coalition" scenario is captured by the coefficients of the two variables $\mathrm{D}_{1}$ and FDI. The impact of the "limited coalition" scenario is captured by including only either one of the variables in equation (1), which is discussed subsequently. The impact of the "stand alone" scenario is captured by the deletion of both variables $\mathrm{D}_{1}$ and FDI from equation (1). Estimating the contribution of each factor to the overall variations in export flows over time is important for evaluating the effectiveness of trade policy toward promoting exports in the home country.

Loulou, Labriet, and Kanudia (2009) analyzed the possibility of achieving five energysaving or carbon emission reduction targets under a full cooperation and a sequential cooperation regime among countries using a stochastic programming approach. As the authors note, however, one major problem with the stochastic programming approach is that it does not consider the impact of non-modeled factors, which could constrain the adoption of some low-carbon technology. Therefore, the impact of non-modeled factors such as behind-the-border constraints on which full information is not available, is included in the stochastic model under an error component approach in this study. The approach is explained in the following paragraphs.

Drawing on Kalirajan (2007), a stochastic frontier gravity equation is estimated to explain the variations in total exports of the focus country by incorporating directly the influence of natural determinants, behind-the-border determinants, mutually induced determinants, and explicit beyond-the-border determinants, for a given level of existing implicit beyond-the-border determinants.

$$
\begin{aligned}
\ln \left(\mathrm{EX}_{\mathrm{i}, \mathrm{j}, \mathrm{t}}\right)= & \mathrm{B}_{1, \mathrm{t}}+\mathrm{B}_{2, \mathrm{t}} \ln \left(\mathrm{PCGDP}_{\mathrm{i}, \mathrm{t}}\right)+\mathrm{B}_{3, \mathrm{t}} \ln \left(\mathrm{PCGDP}_{\mathrm{j}, \mathrm{t}}\right)+\mathrm{B}_{4, \mathrm{t}} \ln \left(\mathrm{DIST}_{\mathrm{i}, \mathrm{j}}\right)+\mathrm{B}_{5, \mathrm{t}} \ln \left(\mathrm{T}_{\mathrm{j}, \mathrm{i}, \mathrm{t}}\right) \\
& +\mathrm{B}_{6, \mathrm{t}} \ln \left(\mathrm{FDI}_{\mathrm{j}, \mathrm{t}-1}\right)+\mathrm{B}_{7, \mathrm{t}} \mathrm{D}_{1}+\mathrm{B}_{8, \mathrm{t}} \mathrm{D}_{2}-\mathrm{u}_{\mathrm{ij}, \mathrm{t}}+\mathrm{v}_{\mathrm{ij}, \mathrm{t}} .
\end{aligned}
$$

PCGDP refers to per capita gross domestic product (GDP). DIST refers to the geographical distance between two major ports in exporting and importing countries. $\mathrm{T}$ is the average tariff rate in the importing country. FDI is the ratio of Asian FDI to total FDI in the exporting country. $D_{1}$ takes a value of 1 , when there are trade agreements between the home and partner countries; otherwise it takes a value of zero. $\mathrm{D}_{2}$ is a year dummy and equal to 1 when the relevant period is considered; otherwise it is zero. The estimation period is 2000 to 2011 . $\mathrm{u}_{\mathrm{ij}, \mathrm{t}}$ measures the negative influence of behind-the-border determinants that exist in the exporting country on which complete information is not known; and $\mathrm{v}_{\mathrm{ij}, \mathrm{t}}$ refers to the normal statistical error term. It is assumed that $\mathrm{u}_{\mathrm{ij}, \mathrm{t}}$ takes a value of zero if there is no significant negative influence of behind-the-border determinants; and it takes a positive value and thereby reduces the level of exports when there exists a significant negative influence of behind-the-border determinants in the exporting country. The parameter $\gamma$ is the ratio of country-specific variation $\left(\sigma_{u}^{2}\right)$ to total variation, that is, $\left(\frac{\sigma_{u}^{2}}{\sigma_{u}^{2}+\sigma_{v}^{2}}\right)$. It indicates 
whether behind-the-border constraints are a determinant of total exports of low-carbon energy technology and services. When $\gamma$ is significant, it implies that behind-the-border constraints are an important determinant of low-carbon technology exports.

Thus, drawing on the framework used in the stochastic frontier production function models (Kalirajan 2007), $\mathrm{u}_{\mathrm{ij}, \mathrm{t}}$ may be assumed to follow a truncated normal distribution $\mathrm{N}$ $\left(\mu, \sigma_{u}^{2}\right)$, truncated at zero, and $\mathrm{v}_{\mathrm{ij}, \mathrm{t}}$ is $\mathrm{N}\left(0, \sigma_{v}^{2}\right)$. Equation (1) is estimated with maximum likelihood using the software FRONTIER 4.1 (Coelli 1996).

To answer the first research question of what will be the magnitude of export flows in low-carbon energy technology and other associated services of the studied countries to their partner countries under the grand regional coalition scenario, the limited cooperation scenario and the stand alone scenario, the following simulations are performed using the estimation results from equation (1):

a) Potential exports of the home country to the relevant partner countries when there are no significant behind-the-border constraints and there is grand regional cooperation, which is proxied by coefficients $\mathrm{B}_{6}$ and $\mathrm{B}_{7}$ associated with variables FDI and $\mathrm{D}_{1}$, respectively, are calculated from the parameter estimates of equation (1) with the assumption that $\mathrm{u}_{\mathrm{ij}, \mathrm{t}}=0$.

b) Potential exports of the home country to the relevant partner countries when there are no significant behind-the-border constraints and there is limited regional cooperation, are calculated from the parameter estimates of equation (1) with the assumption that $\mathrm{u}_{\mathrm{ij}, \mathrm{t}}=0$ and either $\mathrm{B}_{6}=0$ or $\mathrm{B}_{7}=0$.

c) Potential exports of the home country to the relevant partner countries when there are no significant behind-the-border constraints and there is stand alone attitude in the home country are calculated from the parameter estimates of equation (1) with the assumption that $\mathrm{u}_{\mathrm{ij}, \mathrm{t}}=0$ along with $\mathrm{B}_{6}=0$ and $\mathrm{B}_{7}=0$.

To answer the second research question of what are the impacts of behind-the-border constraints on potential export flows in low-carbon energy systems in the region, the ratio of actual export flows to potential export flows under the stand alone scenario (EX $/ \mathrm{EX}^{\mathrm{p}}$ ) is calculated across the selected countries-this provides a measure of how much potential is achieved by the relevant country. A measure of $\left[1-\left(\mathrm{EX}^{\mathrm{a}} / \mathrm{EX}^{\mathrm{p}}\right)\right] \times 100$ shows the relevant country's un-utilized potential due to its behind-the-border constraints.

\section{Data source}

The main data sources are COMTRADE, WITS, and UNCTAD's World Investment Reports covering the period 2000 to 2009. The studied countries are China, India, Indonesia, 
Table 1. Trade in low-carbon energy services: Effective tariffs in emerging Asian economies (\%)

\begin{tabular}{llllll}
\hline Country & $\begin{array}{l}\text { All industrial } \\
\text { goods average }\end{array}$ & $\begin{array}{l}\text { Solar } \\
\text { photovoltaic }\end{array}$ & $\begin{array}{l}\text { Wind } \\
\text { power }\end{array}$ & $\begin{array}{l}\text { Clean } \\
\text { coal }\end{array}$ & $\begin{array}{l}\text { Energy-efficient } \\
\text { LED lighting }\end{array}$ \\
\hline China & 8.57 & 4.16 & 7.65 & 8.03 & 8.03 \\
India & 9.74 & 5.41 & 7.28 & 7.25 & 9.39 \\
Indonesia & 5.84 & 5.93 & 4.81 & 0 & 7.63 \\
Malaysia & 5.91 & 7.51 & 4.39 & 0 & 25.11 \\
The Philippines & 5.0 & 4.97 & 0.84 & 2.07 & 9.88 \\
Singapore & 0 & 0 & 0 & 0 & 0 \\
Thailand & 10.97 & 6.82 & 6.59 & 0.89 & 17 \\
Vietnam & 11.68 & 14.91 & 11.8 & 0 & 32.22 \\
\hline
\end{tabular}

Source: Adapted from Mikic (2010).

Malaysia, the Philippines, Singapore, Thailand, and Vietnam. Technologies covered in this study are the WTO 153 list grouped into 12 categories for analytical purposes. Wider dissemination of these technologies not only has the potential to curb emissions, but also brings local environmental benefits. The categories are: renewable energy plant, energy efficiency equipment, clean coal technology, waste to energy, SOx control, heat and energy management, waste water treatment, energy and environmental monitoring and analysis, energy efficiency labelled products, management of solid and hazardous waste, and natural gas development.

\section{Current patterns of trade and investment in low-carbon energy technology and allied climate smart services}

The effective tariff structure of all industrial goods and low-carbon technology are presented in Table 1. The tariff structure of general technology ranges from 11.7 percent to 5.0 percent and that of low-carbon technology varies from 32.2 percent to 2 percent depending on the technology and the country. Some countries, like China, are major producers and net exporters of solar photovoltaic at the world level, whereas other economies, like Singapore, are net importers.

Production and thereby exports and imports of low-carbon energy technology are mainly determined by technological innovation and investment; the current patterns of exports and imports of such technologies in major Asian emerging economies are shown in Table 2. It is interesting to note that China dominates trade in goods and services of all categories except "waste to energy," in which India dominated from 2000 to 2011. Among the ASEAN emerging economies, Singapore dominates trade, followed by Thailand. Given the difficulties in identifying FDI that is directly connected with the production of the 153 WTO list of low-carbon technology goods and services, estimates from different sources are discussed to examine the overall pattern of investment in low-carbon energy. 
Table 2. WTO 153 list of low-carbon energy technology and allied services

\begin{tabular}{|c|c|c|c|c|c|c|c|c|}
\hline \multicolumn{9}{|c|}{ Panel A: Renewable energy plant (\%) } \\
\hline \multirow[b]{2}{*}{ Country } & \multicolumn{2}{|l|}{2005} & \multicolumn{2}{|l|}{2007} & \multicolumn{2}{|l|}{2009} & \multicolumn{2}{|l|}{2011} \\
\hline & Import & Export & Import & Export & Import & Export & Import & Export \\
\hline China & 45.9 & 25.5 & 39.0 & 32.7 & 43.3 & 42.5 & 43.1 & 46.4 \\
\hline India & 5.4 & 14.6 & 6.0 & 15.6 & 7.9 & 14.1 & 9.1 & 11.2 \\
\hline Indonesia & 11.0 & 5.1 & 16.8 & 4.9 & 10.8 & 4.1 & 12.3 & 3.7 \\
\hline Malaysia & 3.0 & 2.4 & 4.7 & 1.6 & 5.4 & 2.3 & 5.0 & 1.3 \\
\hline Philippines & 1.3 & 0.1 & 1.3 & 0.1 & 1.0 & 0.0 & 0.9 & 0.0 \\
\hline Singapore & 14.3 & 36.7 & 10.5 & 23.7 & 10.6 & 16.4 & 10.8 & 20.2 \\
\hline Thailand & 17.2 & 15.4 & 19.3 & 20.6 & 18.5 & 19.5 & 15.5 & 16.4 \\
\hline Vietnam & 2.1 & 0.3 & 2.3 & 0.8 & 2.5 & 1.0 & 3.4 & 0.8 \\
\hline Total & 100.0 & 100.0 & 100.0 & 100.0 & 100.0 & 100.0 & 100.0 & 100.0 \\
\hline \multicolumn{9}{|c|}{ Panel B: Energy-efficient technology (\%) } \\
\hline & $\underline{2005}$ & & $\underline{2007}$ & & $\underline{2009}$ & & $\underline{2011}$ & \\
\hline Country & Import & Export & Import & Export & Import & Export & Import & Export \\
\hline China & 54.3 & 87.4 & 61.4 & 89.7 & 51.5 & 83.7 & 55.1 & 81.9 \\
\hline India & 3.8 & 2.3 & 8.8 & 2.3 & 10.9 & 4.4 & 9.4 & 5.7 \\
\hline Indonesia & 5.1 & 0.2 & 5.1 & 0.5 & 5.4 & 2.6 & 5.1 & 0.6 \\
\hline Malaysia & 3.3 & 2.3 & 4.1 & 1.1 & 6.5 & 0.9 & 9.2 & 4.3 \\
\hline Philippines & 0.3 & 0.0 & 0.6 & 0.0 & 0.6 & 0.0 & 0.6 & 0.0 \\
\hline Singapore & 9.3 & 5.7 & 7.9 & 3.3 & 14.2 & 5.4 & 10.7 & 4.4 \\
\hline Thailand & 20.3 & 2.0 & 10.4 & 2.9 & 6.5 & 2.9 & 6.8 & 3.0 \\
\hline Vietnam & 3.5 & 0.1 & 1.8 & 0.2 & 4.4 & 0.1 & 3.1 & 0.1 \\
\hline Total & 100.0 & 100.0 & 100.0 & 100.0 & 100.0 & 100.0 & 100.0 & 100.0 \\
\hline \multicolumn{9}{|c|}{ Panel C: Heat and energy management $(\%)$} \\
\hline & $\underline{2005}$ & & $\underline{2007}$ & & 2009 & & 2011 & \\
\hline Country & Import & Export & Import & Export & Import & Export & Import & Export \\
\hline China & 43.0 & 64.3 & 46.7 & 66.5 & 45.4 & 74.1 & 46.6 & 72.2 \\
\hline India & 6.3 & 4.6 & 7.8 & 4.5 & 9.6 & 4.1 & 9.7 & 5.0 \\
\hline Indonesia & 3.6 & 1.9 & 4.0 & 1.2 & 3.8 & 1.0 & 5.9 & 0.9 \\
\hline Malaysia & 7.7 & 3.9 & 7.1 & 4.7 & 6.8 & 3.5 & 5.7 & 3.2 \\
\hline Philippines & 1.7 & 0.7 & 1.1 & 0.5 & 1.0 & 0.3 & 0.8 & 0.2 \\
\hline Singapore & 17.4 & 15.2 & 13.9 & 13.5 & 13.4 & 9.2 & 12.9 & 9.7 \\
\hline Thailand & 17.4 & 8.5 & 17.3 & 8.4 & 16.2 & 7.2 & 15.1 & 7.8 \\
\hline Vietnam & 2.9 & 0.8 & 2.1 & 0.7 & 3.8 & 0.7 & 3.3 & 0.9 \\
\hline Total & 100.0 & 100.0 & 100.0 & 100.0 & 100.0 & 100.0 & 100.0 & 100.0 \\
\hline \multicolumn{9}{|c|}{ Panel D: Waste to energy ( $\%)$} \\
\hline & $\underline{2005}$ & & 2007 & & $\underline{2009}$ & & $\underline{2011}$ & \\
\hline Country & Import & Export & Import & Export & Import & Export & Import & Export \\
\hline China & 30.2 & 6.0 & 49.9 & 6.4 & 31.4 & 4.6 & 25.8 & 11.6 \\
\hline India & 42.6 & 77.7 & 34.9 & 88.6 & 47.7 & 87.4 & 48.1 & 81.0 \\
\hline Indonesia & 6.8 & 1.3 & 7.8 & 0.2 & 10.3 & 0.6 & 8.4 & 1.4 \\
\hline Malaysia & 0.9 & 0.2 & 0.7 & 0.6 & 1.0 & 0.7 & 0.9 & 2.3 \\
\hline Philippines & 0.9 & 0.0 & 0.4 & 0.0 & 0.6 & 0.0 & 0.5 & 0.1 \\
\hline Singapore & 1.9 & 0.7 & 0.8 & 0.5 & 1.2 & 1.6 & 0.6 & 1.2 \\
\hline Thailand & 9.5 & 3.6 & 2.1 & 2.7 & 4.7 & 1.1 & 14.4 & 1.0 \\
\hline Vietnam & 7.2 & 10.4 & 3.4 & 1.0 & 3.1 & 4.1 & 1.2 & 1.5 \\
\hline Total & 100.0 & 100.0 & 100.0 & 100.0 & 100.0 & 100.0 & 100.0 & 100.0 \\
\hline
\end{tabular}

Source: Compiled from COMTRADE database.

Using FDI data on greenfield projects and cross-border mergers and acquisitions data, UNCTAD has recently estimated that three low-carbon technologies, namely, renewables (biogas, solar, and wind), recycling, and energy efficiency equipment manufacturing, have attracted FDI flows amounting to US\$ 90 billion in 2011 (UNCTAD 2012). The 
pattern of FDI in low-carbon energy technology and services is diversified geographically and in terms of types of low-carbon energy and environmental technology. For example, FDI in "alternative/renewable power generation" is concentrated in developed economies, though about 25 percent of investments is in developing countries including the Asian emerging economies of China, India, Indonesia, the Philippines, and Vietnam. In terms of venture capital investments in clean technology, North America, Europe, China, and India attracted about US\$ 8.4 billion from venture capital firms namely, NTEC, Cleantech Ventures, and Foundation Capital. The pattern of clean technology venture capital investments clearly shows an increasing trend, from US\$ 0.5 billion in 2001, to US\$ 2.1 billion in 2005, to US\$ 8.4 billion in 2011. China and India seem to be the current major growth markets for cleantech investments, particularly in renewable energy technologies. Solar accounted for about 40 percent of total clean technology investment and investment in biofuels accounted for 11 percent in 2008.

China invested RMB 200 billion in energy-saving and emission reduction projects, generating investment worth of about RMB 2 trillion during 2006 to 2010. From 2006 to 2012, American firms invested a total of US\$ 6.5 billion in India. India now is one of the largest markets for U.S. clean energy technology. In 2011-12, two of the three U.S. financing agencies approved 173 transactions in India, totalling US\$ 1.4 billion, in solar energy. It is estimated that in the next 20 years India will need investments of over US\$ 1 trillion to improve healthcare, transportation infrastructure, and energy production. In 2011 the World Bank approved a US\$15.36 million credit and a US\$ 8.14 million grant for the Biodiversity Conservation and Rural Livelihood Improvement Project to support the Government of India in its efforts to conserve high-value forest areas with the objective of improving the livelihoods of forest-dependent communities. The project, which will run for six years, will conserve biodiversity while improving rural livelihoods by applying culturally appropriate and tested participatory approaches from the communities to support opportunities for improving rural livelihoods.

\section{Potential exports of low-carbon energy technology and other services under different scenarios}

Using unbalanced panel data for the selected Asian emerging economies over the period 2000 to 2011, equation (1) was estimated using the software FRONTIER 4.1 for total exports of low-carbon goods and services and also for each of the 12 categories of lowcarbon goods and services exports for the individual countries. Table 3 shows the estimation results for total exports of low-carbon energy technology and services.

All the coefficients for individual countries are statistically significant at least at the 5 percent level, which indicates that the selected model explains well the variations in export flows in low-carbon energy technology and services through the selected determining 
Table 3. Estimates of determinants of total exports of low-carbon energy technology and associated services

\begin{tabular}{lcccccccc}
\hline Coefficients & China & India & Indonesia & Malaysia & Philippines & Singapore & Thailand & Vietnam \\
\hline Constant & 10.532 & 9.441 & 8.560 & 9.862 & 7.655 & 9.753 & 7.662 & 7.453 \\
& $(4.235)$ & $(3.311)$ & $(4.104)$ & $(4.226)$ & $(3.812)$ & $(3.546)$ & $(4.475)$ & $(3.893)$ \\
PCGDPe & 0.672 & 0.543 & 0.572 & 0.618 & 0.438 & 0.712 & 0.453 & 0.426 \\
& $(2.042)$ & $(3.176)$ & $(2.342)$ & $(2.008)$ & $(2.499)$ & $(3.102)$ & $(2.641)$ & $(2.227)$ \\
PCGDPm & 0.815 & 0.675 & 0.642 & 0.788 & 0.525 & 0.844 & 0.616 & 0.589 \\
& $(2.003)$ & $(3.452)$ & $(3.117)$ & $(2.567)$ & $(2.338)$ & $(3.756)$ & $(2.114)$ & $(3.129)$ \\
Dist & -0.435 & -0.680 & -0.580 & -0.553 & -0.643 & -0.507 & -0.620 & -0.614 \\
& $(3.234)$ & $(2.768)$ & $(3.278)$ & $(3.443)$ & $(2.786)$ & $(3.651)$ & $(4.126)$ & $(2.057)$ \\
Tariff (\%) & -0.765 & -0.720 & -0.680 & -0.725 & -0.831 & -0.654 & -0.710 & -0.730 \\
& $(2.879)$ & $(3.227)$ & $(4.241)$ & $(3.225)$ & $(4.824)$ & $(3.226)$ & $(4.226)$ & $(3.543)$ \\
FDI ratio & 0.892 & 0.675 & 0.558 & 0.618 & 0.457 & 0.915 & 0.584 & 0.595 \\
$D_{1}$ (PTA) & 1.056 & 0.768 & 0.825 & 0.856 & 0.845 & 0.918 & 0.822 & 0.851 \\
$D_{2}$ (Years) & 0.876 & 0.612 & 0.556 & 0.612 & 0.338 & 0.698 & 0.589 & 0.572 \\
Gamma, $\gamma$ & 0.815 & 0.786 & 0.882 & 0.867 & 0.797 & 0.693 & 0.802 & 0.903 \\
\hline
\end{tabular}

Note: Figures in parentheses are $t$-statistics. All coefficients are statistically significant at least at the 5 percent level.

variables. The statistical significance of $\gamma$ implies that behind-the-border constraints are important determinants of export flows in low-carbon energy technology and services from the selected Asian emerging economies. This result also confirms that the selected model is appropriate to examine the determinants of export flows in low-carbon energy systems from the selected countries. Other interesting results are the magnitude and significance of the variable FDI, which is the ratio of FDI from Asian countries to FDI in the relevant Asian emerging economy, and $\mathrm{D}_{1}$, which shows the existence of trade agreements between the exporting Asian emerging economy and its trading partners. Taken together, these two coefficients indicate the influence of the grand coalition scenario on exports of low-carbon energy systems from the concerned Asian emerging economy. On the other hand, taking either of the coefficients individually indicates the influence of the limited coalition scenario on exports. Though these coefficients are all positive for all the Asian emerging economies, they vary in magnitude across countries. The impact of Asian FDI on exports of low-carbon energy systems is largest for Singapore (0.92) and lowest for the Philippines (0.46). This means that Singapore's low-carbon energy technology exports would increase by 9 percent for every 10 percent increase in FDI from Asian countries. This clearly supports that further research and investment through regional cooperation could lead to substantial benefits.

Another important result that conveys the significance of regional cooperation on improving low-carbon energy technology exports in Asian emerging economies concerns the positive and significant coefficient of the variable $\mathrm{D}_{1}$. The coefficient varies from 1.06 for China to 0.82 for Thailand. The implication is that China's existing trade agreements with other countries have facilitated China's ability to export more low-carbon energy technology and services than other Asian emerging economies, which also have trade agreements with their partner countries. 
Table 4: Potential exports of low-carbon energy systems and services under different scenarios

\begin{tabular}{|c|c|c|c|c|c|c|}
\hline \multicolumn{7}{|l|}{ Panel A: China } \\
\hline \multirow{2}{*}{$\begin{array}{l}\text { Category } \\
\text { Renewable energy plant }\end{array}$} & \multicolumn{2}{|c|}{$\begin{array}{l}\text { Stand alone } \\
\text { (\% increase) }\end{array}$} & \multicolumn{2}{|c|}{$\begin{array}{l}\text { Limited } \\
\text { coalition } \\
\text { (\% increase) }\end{array}$} & \multicolumn{2}{|c|}{$\begin{array}{l}\text { Grand } \\
\text { coalition } \\
\text { (\% increase) }\end{array}$} \\
\hline & 2005 & 2011 & 2005 & 2011 & 2005 & 2011 \\
\hline Cleaner energy efficiency technology & 20 & 22 & 26 & 28 & 32 & 33 \\
\hline Heat and energy management & 30 & 28 & 32 & 33 & 35 & 33 \\
\hline Waste to energy & 28 & 30 & 31 & 32 & 33 & 36 \\
\hline Remediation of waste & 40 & 35 & 42 & 38 & 44 & 34 \\
\hline Pollution SOx control & 35 & 33 & 37 & 35 & 38 & 41 \\
\hline Energy audit and monitoring & 38 & 35 & 39 & 36 & 40 & 36 \\
\hline Energy and eco-labbeled products & 42 & 43 & 45 & 45 & 47 & 37 \\
\hline Natural resources protection & 38 & 35 & 40 & 37 & 41 & 48 \\
\hline Natural risk management & 44 & 35 & 45 & 43 & 46 & 38 \\
\hline Noise and vibration abatement & 45 & 42 & 47 & 48 & 49 & 44 \\
\hline Waste management & 28 & 36 & 39 & 40 & 32 & 30 \\
\hline \multicolumn{7}{|l|}{ Panel B: India } \\
\hline Category & \multicolumn{2}{|c|}{$\begin{array}{l}\text { Stand alone } \\
\text { (\% increase) }\end{array}$} & \multicolumn{2}{|c|}{$\begin{array}{l}\text { Limited } \\
\text { coalition } \\
\text { (\% increase) }\end{array}$} & \multicolumn{2}{|c|}{$\begin{array}{l}\text { Grand } \\
\text { coalition } \\
\text { (\% increase) }\end{array}$} \\
\hline Renewable energy plant & 2005 & 2011 & 2005 & $\frac{111}{2011}$ & 2005 & 2011 \\
\hline Cleaner energy efficiency technology & 30 & 32 & 31 & 33 & 32 & 34 \\
\hline Heat and energy management & 31 & 32 & 32 & 33 & 34 & 35 \\
\hline Waste to energy & 32 & 32 & 34 & 35 & 35 & 36 \\
\hline Remediation of waste & 40 & 42 & 42 & 43 & 44 & 44 \\
\hline Pollution SOx control & 37 & 38 & 39 & 40 & 40 & 42 \\
\hline Energy audit and monitoring & 38 & 37 & 39 & 38 & 40 & 40 \\
\hline Energy and eco-labelled products & 28 & 26 & 30 & 28 & 32 & 30 \\
\hline Natural resources protection & 40 & 42 & 42 & 43 & 44 & 45 \\
\hline Natural risk management & 37 & 47 & 39 & 37 & 40 & 38 \\
\hline Noise and vibration abatement & 46 & 32 & 47 & 48 & 49 & 50 \\
\hline Waste management & 30 & 38 & 32 & 33 & 34 & 35 \\
\hline \multicolumn{7}{|l|}{ Panel C: Indonesia } \\
\hline \multirow{2}{*}{$\begin{array}{l}\text { Category } \\
\text { Renewable energy plant }\end{array}$} & \multicolumn{2}{|c|}{$\begin{array}{l}\text { Stand alone } \\
(\% \text { increase })\end{array}$} & \multicolumn{2}{|c|}{$\begin{array}{l}\text { Limited } \\
\text { coalition } \\
\text { (\% increase) }\end{array}$} & \multicolumn{2}{|c|}{$\begin{array}{l}\text { Grand } \\
\text { coalition } \\
(\% \text { increase })\end{array}$} \\
\hline & 2005 & 2011 & 2005 & $\frac{2011}{2011}$ & 2005 & $\frac{\cos (1)}{2011}$ \\
\hline Cleaner energy efficiency technology & 28 & 27 & 30 & 28 & 32 & 30 \\
\hline Heat and energy management & 27 & 30 & 31 & 32 & 33 & 34 \\
\hline Waste to energy & 38 & 35 & 39 & 36 & 40 & 37 \\
\hline Remediation of waste & 42 & 43 & 45 & 45 & 47 & 48 \\
\hline Pollution SOx control & 30 & 28 & 32 & 33 & 35 & 36 \\
\hline Energy audit and monitoring & 20 & 22 & 26 & 28 & 32 & 33 \\
\hline Energy and eco-labelled products & 40 & 35 & 42 & 38 & 44 & 41 \\
\hline Natural resources protection & 35 & 33 & 37 & 35 & 38 & 36 \\
\hline Natural risk management & 38 & 35 & 40 & 37 & 41 & 38 \\
\hline Noise and vibration abatement & 44 & 42 & 45 & 43 & 46 & 44 \\
\hline Waste management & 45 & 47 & 47 & 48 & 49 & 49 \\
\hline
\end{tabular}

Table 4 shows the potential increase in exports of low-carbon energy technology by category each studied economy would achieve under the grand coalition, limited coalition, and stand alone scenarios. These scenarios are simulated with the assumption that there are no "behind-the-border" constraints to exports in those emerging economies. 
Figure 2. Mean inefficiency in export flows in low-carbon energy technology and services

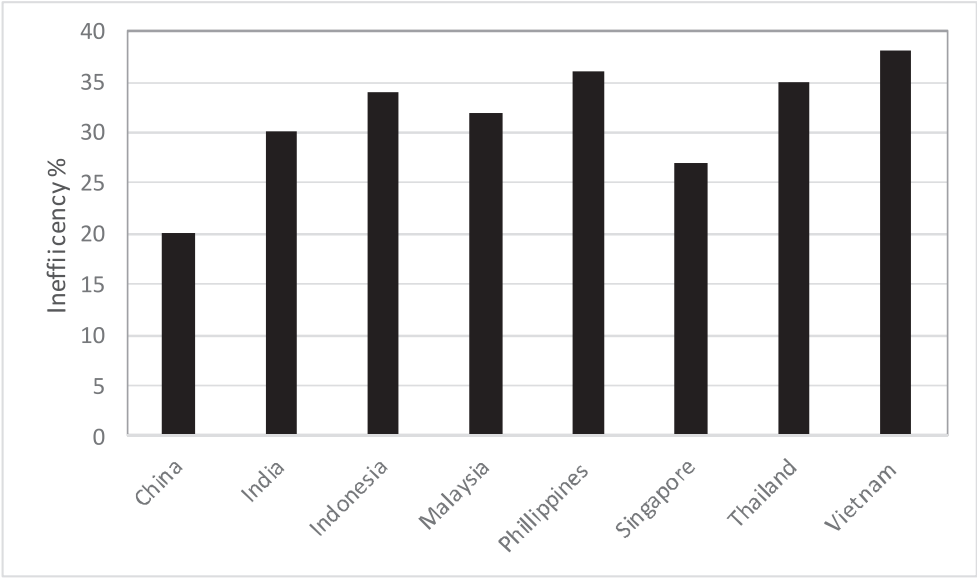

All Asian emerging economies enjoy greater export potential in a grand coalition than a limited coalition. Nevertheless, the percentage increase varies across countries; China and Singapore appear to enjoy greater export potential in the majority of categories. The implication of these results is that regional cooperation in the form of a grand coalition can certainly increase the export potential in low-carbon energy technology in emerging economies, which would accelerate the pace of transforming Asia into Green Asia.

Such a transformation will not come without careful tailoring of the existing energy policies and agreements relating to matters such as preferential or free trade agreements entailing the removal of barriers to trade in goods and services, particularly with ASEAN countries, China, and India.

Also equally important is the elimination of behind-the-border constraints that exist within the exporting country, such as poor infrastructure and inefficient institutions, which create the gap between actually realized and potentially possible exports. The gaps between the actual and potential exports are calculated for each year from 2000 to 2009 and the average gaps for the selected eight Asian emerging economies are presented in Figure 2.

The results indicate that China's gap between its actual and potential exports is the smallest, which means that on average China is able to realize 80 percent of its potential exports. Singapore is able to realize 73 percent of its potential exports, whereas the figure for India is 70 percent. Vietnam appears to be realizing only about 62 percent of its export potential in low-carbon energy technology and associated services. It would be interesting 
to examine what specific behind-the-border constraints contribute to such gaps in these countries. Due to lack of appropriate data across the countries over the period of analysis, identification of specific constraints could not be done in this study.

\section{Conclusions}

Trade has been a main source of growth for East Asia, and this has been nurtured over the years through the creation of production networks. Such an industrial agglomoration has also increased the demand for energy use in South and Southeast Asia. The experiences of East Asian countries encouraged other ASEAN countries to get connected to East Asian countries either directly or indirectly. Thus, Asian countries appear to be moving steadily toward a greater Asian integration. With the increasing attention of attaining energy security and the necessity to implement Intended Nationally Designated Contributions to abate climate change, each country is showing a keen interest to increase low-carbon energy uptake. Unfortunately, production, trade, and investment in these technologies are still very low regionally. This means that there is a large gap between the demand for and the supply of low-carbon energy technology and associated pollution abatement services-only 50 percent of the low-carbon energy technology and associated pollution abatement services that are to be used by 2030 are available to developing countries of Asia. This supply gap provides an opportunity for those economies, which have the potential to contribute to the manufacturing of such technologies individually and collectively pooling their physical and human capital. How to materialize the existing opportunity across Asia, and globally, depends on country-specific and region-specific factors that need further focused studies.

\section{References}

Ando, Mitsuyo, and Fukunari Kimura. 2003. The Formation of International Production and Distribution Networks in East Asia, International Trade in East Asia, NBER-East Asia Seminar on Economics, Volume 14. Cambridge, MA: National Bureau of Economic Research.

Choi, Nakgyoon. 2001. Determinants of Staging Categories for Tariff Elimination in Chinese, Japanese, and Korean Negotiations of Free Trade Agreements. Asian Economic Papers 10(2):1-17.

Coelli, Timothy J. 1996. A Guide to FRONTIER Version 4.1: A Computer Program for Stochastic Frontier Production and Cost Function Estimation. Centre for Efficiency and Productivity Analysis Working Paper No. 78/96. University of Queensland.

Gill, Indermit, and Homi Kharas. 2007. An East Asian Renaissance: Ideas for Economic Growth. Washington, DC: The World Bank.

Golub, Stephen S., Christine Kaufmann, and Philip Yeres 2011. Defining and Measuring Green FDI: An Exploratory Review of Existing Work and Evidence. OECD Working Papers on International Investment, No. 2011/2. Paris: OECD Investment Division.

Huff, Gregg. 1999. Singapore's Economic Development: Four Lessons and Some Doubts. Oxford Development Studies 21(1):33-35. 
Kalirajan, Kaliappa. 2007. Regional Cooperation and Bilateral Trade Flows: An Empirical Measurement of Resistance. International Trade Journal 21(2):85-107.

Kawai, Masahiro, and Ganeshan Wignaraja. 2008. Regionalism as an Engine of Multilateralism: A Case for a Single East Asian FTA. Working Papers on Regional Economic Integration No. 14. Manila: Asian Development Bank.

Kimura, Fukunari, and Mitsuyo Ando. 2005. Two dimensional Fragmentation in East Asia: Conceptual Framework and Emprirics. International Review of Eonomics and Finance 14(3):317-348.

Kodama, Naomi, and Tomohiko Inui 2015. The Impact of Globalization on Establishment-Level Employment Dynamics in Japan. Asian Economic Papers 14(2):41-65.

Lackner, Klaus S. 2005. The Conundrum of Sustainable Energy: Clean Coal as One Possible Answer. Asian Economic Papers 4(3):30-58.

Loulou, Richard, Maryse Labriet, and Amit Kanudia 2009. Deterministic and Stochastic Analysis of Alternative Climate Targets Under Differentiated Cooperation Regimes. Energy Economics 31: S131S143.

Mikic, Marija. 2010. Trade in Climate Smart Goods: Trends and Opportunities in Asia and the Pacific. Paper presented at the Regional Symposium on Low Carbon Economy organized by ESCAP in Bali, Indonesia, 13-14 October.

NDRC. 2009. China's Policies and Actions for Addressing Climate Change-Progress Report November. Beijing: National Development and Reform Commission.

Siow Yue, Chia. 2015. Emerging Mega-FTAs: Rationale, Challenges, and Implications. Asian Economic Papers 14(1):1-27.

Sjöholm, Fredrik, and Nannan Lundin. 2010. Will Science and Technology Solve China's Unemployment Problem? Asian Economic Papers 9(2):1-28.

Song, Backhoon. 2015. Location Proximity and Productivity Spillovers: The Case of Korean Manufacturing Plants. Asian Economic Papers 14(1):104-118.

Streets, David G. 2005. Black Smoke in China and Its Climate Effects. Asian Economic Papers 4(2):358 .

Sung, Hankyou. 2012. Delays in Multilateral Trade Negotiations: An Experimental Study. Asian Economic Papers 11(1):160-176.

UNCTAD. 2012. World Investment Report 2010: Investing in a Low Carbon Economy. Geneva: United Nations Conference on Trade and Development.

Wakasugi, Ryuhei. 2007. Vertical Intra-Industry Trade and Economic Integration in East Asia. Asian Economic Papers 6(1):26-39.

Wignaraja, Ganeshan. 2008. FDI and Innovation as Drivers of Export Behaviour: Firm-level Evidence from East Asia. UNU-MERIT Working Paper Series No. 061. United Nations University, Maastricht Economic and Social Research and Training Centre on Innovation and Technology.

Wignaraja, Ganeshan, Peter Morgan, Michael G. Plummer, and Fan Zhai. 2015. Economic Implications of Deeper South Asian-Southeast Asian Integration: A CGE Approach. Asian Economic Papers 14(3):63-81. 